\title{
Legal Position - International Recognition of Kosovo and the Right to "Self-Determination"
}

\author{
Elton Musa \\ Lecturer University "Alexander Moses" Durres, Phd.Candidate. \\ musaelton@yahoo.com \\ Aldo Shkembi \\ Lecturer European University of Tirana, Phd. \\ aldo-sh86@hotmail.com
}

\begin{abstract}
.
This article aims to analyze the legal process - international state of Kosovo and the right to self-determination, where especially trading special attention will be paid to the ratio between the State and their citizens in relation to the right of the latter to decide, should be considered in the framework of international law perspective. Firstly comes treating theoretical framework, over which viewed, meaning international recognition and the possibility of finding the best solution for the citizens. The treatment of recognition of Kosovo in this article comes as one of the particular cases to a universal case, this case will be treated to the formation of new states and their announcement based on the principle of "self-determination". Current political status of Kosovo is the result of adherence to legal and geopolitical constraints that have been made at different times by the policy of major countries expressed through this cognitive status and interests of citizens and beyond the interests of international politics. This article examines the phenomenon of Kosovo's case, in the context of a historical treatment and selfLegal as the principle of "self-determination" is also the point of incorporation between history, doctrine of international and domestic law of a country. In this context the case of Kosovo as a case of "sui generis" international rights doctrine. The right of people and nations to self-determination is a prerequisite for full use of all basic human rights.
\end{abstract}

Keywords: self-determination, human rights, international law, the internal law, Nation.

\section{INTRODUCTION}

The analysis comes and treated in this article as the will of a people and a direct expression of the principle of "selfdetermination", the study takes an analysis of the resolution in the Ahtisaari package and the common elements that refer to and derive directly in Kosovos Constitution. What are the problems that Kosovo is facing today, and what impact does the decision of the International Court of Justice, all this comes and treated as a precondition for respect of human rights in its entirety as human beings. The community of people within a state, in fact, that you are guaranteed the right to express themselves, to live according to his faith, its customs and traditions, to preserve its language, its religion, and at the end of last identity.

Treatment of recognition of Kosovo in this article comes as one of the particular cases to a universal case, this case will be treated to the formation of new states and their announcement based on the principle of "self-determination". Current political status of Kosovo is the result of adherence to legal and geopolitical constraints that have been made at different times by the policy of major countries expressed through this cognitive status and interests of citizens and beyond the interests of international politics. The debate on self-determination is strongly discussed in recent years throughout Europe. Given that interweave a whole political emotions and economic interests is difficult to find clear information about what really is and what is happening, but Top Chan's new state a social-political formation comes to us based the elements that must fulfill itself to recognized as a subject with full attribution in international law. In article will stop at one of the elements of the state, and precisely for addressing sovereignty and intervention for humanitarian purposes as a new concept evolving even nowadays the international doctrine. 


\section{PRINCIPLE self-determination in international law}

The principle of "self-determination" is part of the group of fundamental principles of international law, its application in practice is associated with significant consequences that occur as we enrich the world stage with its stateholders as well as the presentation of the states. As a principle of international law it is connected and conditioned in some way with several other institutes it. Establishing the principle of "self-determination" in the international legal background and treatment of evaluation and its aspects will serve us to better understand the importance actual cases in which this has been implemented. Therefore we will focus initially on the general framework of international doctrine and basic elements of the state as a subject of international law for international recognition. With the development of human society in a world already featured towards the respect of human rights and fundamental freedoms equally became necessary that regardless of where the individual, respect for these rights is very important.

Through an analysis of the following about international law, domestic law and international legal norms generally as a function of regulation of relations between states will examine the concept and operation of where it is and where is the principle of "self-determination", nowadays ${ }^{1}$. The international law constitutes a system of norms and principles governing international relations strain sovereign states and other institutional entities of international law These rates are created before all of the states or to their interests or as a tool to facilitate the functioning of member organizations of which they are. International Law in a broader sense it includes every aspect of interstate activities and facilities the functioning of the international community. Precisely the development of international law by a system that was primarily to facilitate international cooperation between entities (states), a system that aims much more control of his subjects constitutes the most prominent feature of the history of law international in recent years.

\section{II.I. THE NOTION AND REPORT international law and domestic law as a meeting point of the principle of "self- determination"}

Based on the theory that the modern legal science division accepted in domestic law and in international law, both those rights will be part of the analysis for the concrete relationship between them. Starting from the principle of "selfdetermination" will express the common meeting point for this principle occurs precisely in the relationship between the domestic law. The law of a State separation is through the establishment of provisions in the highest normative act within the state (constitution of a country). Through a set of norms (constitution) determine which international norms hierarchy will be placed and what is the ratio between internal normative acts and international rate.

In its basic definition of international law is defined as a set of legal norms that regulate relations between countries, in this context, the principle of "self-determination"2 includes two main aspects: the aspect of internal and external aspects, the first aspect means that walking through make them feel free to choose and state economic order after. None intervention from outside. While the external aspect has origin in full independence where the state as a result declared by the people on whose behalf it was created chooses to be represented in the international community. The principle of selfdetermination for people choosing to split, join or rejoin a nation state or another.

Right interior may take a definition as the entirety of legal norms concerning the status (position) of state and government officials, as well as the norms that regulate relationships between government officials and citizens. 3 Relationship between international law and domestic law always expressed in the form of a debate between them, for the reason that no collision stand by theorist and researcher of international doctrine if these two components of international law can be synchronized or approximated between them in solving The issue, not to the prejudice each other. This discussion of the researchers treated three main theories afflictions such as nihilistic, dualistic theory and the theory of the primacy of international law.4 According to the first theory which is based on the views of Hobbes and Spinoza, which expressly states that international law unlikely to compete with domestic law Sese not exist as a right-genuine, but it can be as a code of rules that have only moral force and not a system of norms and legal acts produced by a sovereign legal authority.

While it dualistic theory of second with typical representatives and Italian General TRIEPEL Anziloti, says: international law and the rights of domestic are two separate systems that change each other by springs, regulating relations and entities that have, but however not exclude and establishing a ratio between them. But the theory of primacy of international law, not only accept international law as an independent system of norms and rules of behavior, but argue that it is a higher legal order, and therefore it is important that the right of specific internal states. Given all three theories in international 
right, we can say that the theory of the primacy of international law, lies closer to the concept of today among these rights report that internal and international.

\section{III: The right to self-determination in case of Kosovo}

The idea of a self-determination in Albanian territories, and their political demands to establish an autonomous status politico-territorial were inseparable part of the history of the Albanian people. Kosovo and the Albanian issue was the subject of historical injustice, aimed the substance of the Albanian people and narrowing of the more his land.

The first attempt in the history of the Albanian people, in which we find elements of the principle of self-determination was the organization of the Albanian League of Prizren (1878-1881). You can say that we find elements of the principle of self determination for exactly this setup politico-administrative-territorial organization provided for a full political independence and territorial. Its aim was to unite the Albanian lands and their independent declaration. "Kosovo in centuries represent a collective of independent legal and political elements and territorial, which excelled with an ethnic Albanian majority. Throughout history, Kosovo has been an autonomous whole territorial. ${ }^{5}$

League took over the major historical tasks: fight for the preservation of the Albanian lands against their cleavage in favor of chauvinistic Balkan monarchies and ensuring autonomy of Albania, the establishment of a national unified Albanian state. ${ }^{6}$ Ambassadors Conference in London in 1912-1913 is another milestone, but which marked the division of Kosovo. Ambassadors Conference interests of Albania was signed in particular by the attitude of Russia, this conference separated Albania leaving out Chameria and Kosovo and other regions with compact Albanian population.Addressing problems limit the new Albanian state relied on considerations not ethnographic, historical, economic, etc., but became the powers under the prism of the maintenance that "European concert", which, in the view of this diplomacy, could lead to an European revolt. $^{7}$

While the separation of Kosovo from Albania should not be considered as a right of Serbia because, as expressed prof. R. Gurakuqi: "This country has to define it: the right of Serbia over Kosovo was not born as a result of a consensus smooth integration of this territory, as a result of a popular general consensus, or a historical continuity unduly interrupt but as a result of winning this territory as booty and internationally sanctioned by an institution, which in its core work were not present basic principles governing international relations democracy to the principle of conservation by all means and ways of concept European. Another important organization in the history of the Albanian people is the Bajan Conference of December 31, 1943, which continued work until 1 to 2 January 1944. This conference has a special importance, because it organized a meeting of all Albanians Plain Dukagjinit Kosovo and Albanians, Serbs, Montenegrins, etc., which expressly stated that: "Dukagjini Plain Kosovo is a province inhabited by a majority of the Albanian people, who, as always, want to join Albania.

Conference highlights Bajan resolution through three main elements, which determine right of self-determination of the Albanian people in Kosovo:

\section{Ethnic element, whereby the Albanian people are self determinated.}

His stems from compacts layout in majority in that territory;

2. The historical element, i.e. antiquity of habitability that this region of the Albanians and the historical community of its existence;

3. The political element, or the expression of political will plebiscite to join a state, in this case Albania, as a secular goal and current Kosovo Albanians whose formulation different faces as the Albanian people want to join. ${ }^{8}$

However that the decisions of the Conference were never considered by the leadership of the Yugoslav state parties, for Albanians it is a reference for the treatment of the Albanian issue. 


\section{ISSUES OF RECOGNITION AND CONSTITUTIONAL-LEGAL POSITION}

1946 Constitution defines Kosovo as an autonomous province and as a constituent element of federalism, and will also situated in the context of constitutional structure during this phase serbise. ${ }^{9}$ Kosovo has been a political subjectivity which expressed its representation to right in the National Assembly to RFPJ-that. Organization and functioning of the organs as seen and Kosovo during this period adjusted to the status of 1948 which was the highest legal act.

Kosovo Statute 1948 was the first act of the general normative Kosovo, which has expressed a form of independence in organizational sphere, but always to the extent that could allow the then centralist system. In this act, overall highest act politico-legal, regulated are important matters such as scope of the provincial authorities, local power organization and also the extraction of all the acts of normative character. As the highest bodies of Kosovo, during this period were the People's Council, the Provincial Executive Council and provincial administration bodies. During this period, Kosovo has enjoyed autonomy in the judicial sphere; in the territory of Kosovo were formed four district courts and the district court, as the court of second instance, while there was Supreme Court, as the highest judicial instance. By extracting the second status since 1953 Kosovo enjoyed few, such as: regulating matters of interest to the Province in the field of economy, of education, culture, popular health and social care, care for enforcement and maintenance of public order. Kosovo as an autonomous province, exercise supervision of legality in the work of popular councils in its territories, reveal the social plan and budget of the province, except for the rights that the Constitution and the law were in the exclusive competence of the bodies Republic. ${ }^{10}$

In relation to the Albanians of Kosovo, the Serbian period, we have a policy, which is to the detriment of the Albanian people. In 1966, the public political scene of Kosovo appeared and articulated demand for the Republic of Kosovo status, request that through the attitudes of the Communist Party, under the dominant influence Serbian, was rejected. The rejection of this reasonable request of the Albanian people of Kosovo was one of the main reasons that prompted the organization of the demonstration Student 1968, which was required to advance the constitutional position of Kosovo and providing a national status for Kosovo.

Constitutional Acts, launched recent developments that are happening in Kosovo in 1968 years, demonstrations and reactions contrary to the former Yugoslavia, essentially changed the character of the independence of Kosovo, we compare it with its position, the first sanctioned Laws Constitutional 1953 and 1963. The main difference stands in restoring the attribute "constructive", according to which Kosovo (like Vojvodina), were designated as a constructive part of the federal structure of the former Yugoslavia. Kosovo adopted the Constitution as the act of senior legal to 02/24/1969. Alongside this constitutional law, Kosovo enjoyed a wider legislative authorization. So previous normative powers, normative character, replaced in this case with broader powers.

The constitutional law of Kosovo represent a fundamental act of a political and legal nature of the Province, which for the form, content, techniques and its extraction was similar to the constitution, unlike previous periods when the rights and duties of autonomous region treated as delegated or transferred from the republic, according to the new constitutional law, the provinces were carrying functions of normative source, in a manner similar to the republics. But anyways, even the definition of the term is an essential difference; when were so similar to the republics, although not enjoyed the same name. For the sole reason that, despite this autonomous with this law was growing, still should not put into question the autonomy of the republic.

In connection with this issue, Prof.. Education Eid says "called the law and not the constitution, as there never existed specific explanations, but is treated more as a result of political compromise through professional whose efforts have been made to preventing doubt that autonomy is breastfeeding the republic than the expression of content and essences that tij. Extraction of the Constitution of the former Yugoslavia in 1974 and continued the process of advancing the position that Kosovo's Constitution in the context of the Yugoslav federalism. Kosovo with the provisions of this Constitution was determined as autonomous political unit territorial and constitutional autonomy. Constructive element position of this year was very special launch legal-constitutional position they enjoyed in relation to other former republics although the provisions of this Constitution does not expressly define, it can be said that Kosovo was an autonomous unit of federal and constructive elements.

This Constitution for Kosovo has a special importance, as it gives it the right to self-determination of the new statutoryconstitution of its position after the collapse of RSFJ-se. Constitution of 1974, Kosovo was an autonomous political-territorial 
units after independence constitutional and legislative sphere. Constitutional because Kosovo has had an organization in order to develop the federation, in the political, economic and social, an organization's own internal, legislative sphere, Kosovo has been carrying sovereign source of legislative regulation of all social relations that have was in the interest of the citizens living in Kosovo, however, the legislative function, had limitations, as well as federations themselves have been limited to the same extent with "federal legislation", which has been under jurisdiction of the federal authorities. ${ }^{11}$

All these attributes that define his 1974 Constitution, despite essentially look like elements of independence and functioning as NCS independent state, with its own organization to a self-governing, Kosovo Albanians could not express their selfdetermination in relation to the former -Federation. It neither can join Albania nor can split the former republics. Kosovo can self-govern and organize themselves, see it always in the spirit of former RFPJ-that there could be a limit may be known a territory, a majority Albanian population, a representative assembly, a court, first as a province within Serbian autonomous federations.

\section{DECISION AND INTERNATIONAL MANAGEMENT OF KOSOVO}

With NATO intervention starts a new historic era for Kosovo, the beginning of the international administration in Kosovo starts with 1944, which approved after the entry of NATO forces in Kosovo. 1944 is an initiative of. Security Council on 10 June 1999, in which placed Kosovo under UN administration, paving way international military and civic presence in the territory of Kosovo, predicted What resolution? For this purpose, in essence, the resolution provided for the establishment of a temporary international administration (UNMIK), on top of which should be a special representative of the SecretaryGeneral of the United Nations. This administration will establish and oversee 'development of self-government and democratic institutions' in Kosovo, including the organization of free elections. Expected, also, the final removal of all Serbian forces from Kosovo, as well as termination of any military action by the UC, K and Albanian Medical Ethics Manual armed groups. To guarantee peace Resolution 1244 and, consistent with placement of a military force NATO to Kosovo. ${ }^{12}$ The international administration is temporary character $\cdot$ and aims to create favorable conditions for solving democratic Kosovo's final status, this model is specific because, besides establishing international civil and military administration, it is combined with a local self-government and a democratic process. and institutional, which along with the elimination of the causes of the crisis and inter-ethnic hostilities, aims to deal with the elimination of the reasons that caused the crisis, then solve the source of the crisis and enable a political solution to the crisis status long hours.

International mission, through Resolution 1244 and the Ahtisaari package aims deployment of talks and cooperation, for the start of negotiations between the Albanians of Kosovo and the Republic of Serbia, These are the two parties that directly refers package and resolutions, which party would always collaborate with third parties, it international. .Negotiations between the parties as it is happening? International mission in Kosovo through a resolution, the Constitutional Framework for Provisional Self, Ahtisaari package and then Kosovo Constitution tries to reach an agreement and cooperation, aiming at launching negotiations between Kosovo and Serbia. Expressed Kosovo and the Republic of Serbia, because at first acts for Serbia used the term Republic, while just called Kosovo Albanian side, 1244 and the Ahtisaari package are two basic documents, which begin functioning foundations of Kosovo. In addition, we will look at some of the main points that deal with these official documents, which not only provide for the temporary self Kosovo but also the launch of a new era for.

In legal and political terms, 1244 has sanctioned the state of the status quo, i.e. the situation that existed before the demolition constitutional position of Kosovo as defined by the 1974 Constitution of 1244, in Annex 2 (item 5) to its rider to Other sets for Kosovo: Establishment of an interim administration for Kosovo as part of an international civil presence under which the people of Kosovo can enjoy substantial autonomy within the FRY, will be decided by the Security Council of the United Nations. The interim administration to provide transitional administration, while establishing and overseeing the development of provisional democratic self-governing institutions to ensure conditions for a peaceful and normal life for all inhabitants of Kosoves. ${ }^{13}$

As for legal temporary status, 1244 for Kosovo promotes a new status, the self-government (autonomy) substantially within integrity FRY. It is precisely this definition, therefore substantial self-governance on the one hand and on the other hand the territorial integrity of the FRY, which brings problems in practical terms self-administration. The concept of substantial government, which promoted in 1244, from which he will also refer to the following Constitutional Komiza for Provisional Self brings a problem in terms of management and in its entirety as essentially that of the legal position of Kosovo. This 
self-government does not contain the necessary attributes, that the rank Kosovo as a state entity, but with attributes which distinguish as autonomous units with limited powers. Although promotes the concept of self Resolution on Kosovo, she attributes the Mission of the United Nations Interim Kosovo (UNMIK-u) the final authority, the functioning of power in Kosovo in his three traits: the legislative, executive and gjyqesor.

These attributes the find as the 1244, as well as the Constitutional Framework for Provisional Self-Government in Kosovo, Resolution 1244 defines a restriction on the mandate of the International Mission for Kosovo, not clear defined powers between international authority and democratic institutions of Kosovo, but by treating them simply as cooperating. It does not set a time for an international defining mission nor the mechanism's final political status of Kosovo, but gives her a temporary nature and pending a final settlement. Another document important is the Ahtisaari package with March 26, 2007. The package is a comprehensive proposal for resolving the status of Kosovo, Based on the principle of selfdetermination, this package provides a condition for the status of Kosovo where its Article 1.8 stipulates that: "Kosovo will have no territorial claims against any state or any state and will not require any state union or part of any state "Ahtisaari package is the starting point for drafting the Constitution of Kosovo, which is in Article 113:" Kosovo shall adopt a Constitution. The Constitution of Kosovo shall prescribe and guarantee the legal and institutional mechanisms, which are essential to ensure that Kosovo is governed by the highest democratic standards, and which will promote peaceful coexistence and prosperity of all residents as . The Constitution will include principles and provisions included in Annex I to this Agreement, but will not be limited to them. ${ }^{14}$

The concept of substantial government, which promoted in 1244 , from which he will also refer to the following Constitutional Komiza for Provisional Self brings a problem in terms of management and in its entirety as essentially that of the legal position of Kosovo. This self-government does not contain the necessary attributes, that the rank Kosovo as a state entity, but with attributes which distinguish as autonomous units with limited powers. Although promotes the concept of self Resolution on Kosovo, she attributes the Mission of the United Nations Interim Kosovo (UNMIK-u) the final authority, the functioning of power in Kosovo in his three traits: the legislative, executive and gjygesor.

These attributes the find as the 1244, as well as the Constitutional Framework for Provisional Self-Government in Kosovo, Resolution 1244 defines a restriction on the mandate of the International Mission for Kosovo, not clear defined powers between international authority and democratic institutions of Kosovo, but by treating them simply as cooperating. It does not set a time for an international defining mission nor the mechanism's final political status of Kosovo, but gives her a temporary nature and pending a final settlement. ${ }^{15}$

\section{Another document important is the Ahtisaari package with March 26, 2007.}

The package is a comprehensive proposal for resolving the status of Kosovo, Based on the principle of self-determination, this package provides a condition for the status of Kosovo where its Article 1.8 stipulates that: "Kosovo will have no territorial claims against any state or any state and will not require any state union or part of any state "18 Ahtisaari package is the starting point for drafting the Constitution of Kosovo, which is in Article 113:" Kosovo shall adopt a Constitution. The Constitution of Kosovo shall prescribe and guarantee the legal and institutional mechanisms, which are essential to ensure that Kosovo is governed by the highest democratic standards, and which will promote peaceful coexistence and prosperity of all residents as\}. The Constitution will involve principles and provisions included in Annex I to this Agreement, but will not be limited to them. "The decision of the Court of Justice on Kosovo was based "on the initiative of Serbia , where the General Assembly of the UN adopted the 8 October 2008 Resolution 63/3, through which, based on Article 96 of the UN Charter and Article 65 of the Statute of the International Court of Justice, the latter was required to give advisory opinion regarding the question: "Is the unilateral declaration of Independence, taken from governmental institutions of Kosovo, in accordance with the right nderkombetare. ${ }^{16}$

Decision advisory International Court of Justice was announced on 22 July 2010. The Court confirmed that the "Declaration of Independence of Kosovo of 17 February 2008 did not violate the norms of international law". This decision received 10 votes in favor and four against. Advisory Opinion of the Court addressed among others some issues, such as judicial and discretion of the court, space and understanding of the issue, the main acts. The court also stopped in assessing whether the declaration of independence was in accordance with international law and general conclusions.

Court gives sc query response submitted by the General Assembly of the UN to address the principle of self-government. "The Court notes at the outset that especially during the second half of the twentieth century 'of international law on the 
issue of self-determination is developed in such a way that the resort has recognized the right of peoples independence in territories where there govern themselves, and people placed under elected, rule and foreign rule. A large number of states are created as a result of the exercise of this right '.

Despite, she pointed out that there were $\cdot$ other examples of declaration of independence outside this context and that 'the practice of States has not raised the issue of adopting a new norm of international law to stop the declaration of independence in these cases. The court then stopped the arguments of some states regarding the borderlines of the right to self-determination and assessing whether or not there is a right to 'disconnect (remedial Secession - disconnection as a last resort). Regarding the handling of the issue given the "right to separate from a state", the Court held that "as may be determined easily by the arguments of all the countries participating in judgment, this problem goes beyond the scope of the assessment to the question posed by the General Assembly. "Where, according to it, to answer the question, it is necessary only to determine" whether the statement violates the norms of general international law created by Resolution 1244 (1999) Security Council.

Where the decision of the International Court of Justice concludes that the norms of general international law not found any concrete ban on the declaration of Independence, therefore, and the "Declaration of Independence of 17 February 2008 did not violate general international right" .

\section{CONCLUSIONS}

Thesis research on this topic starts with the basics of a fundamental principle, that of self-determination of people in general, which directly call and affect states.

Issues of separation and the union of the states are the most debated topics today in the international arena, the principle of self-determination that President Wilson in 14 points of his program until nowadays with the case of Kosovo brings an evolution of this principle.

The will of people to secede from a state or to be declared independent in the international arena today judged case by case, and therefore recent changes in the political map of Europe and not only those cases were more specific attribute, "sui generis". We are working all supported not only in the history of nations or states, but also the basics of legal doctrine, the main institutes and, crucially, the impact of the principles of international law for the establishment of the State and respect human rights.

In the case of Kosovo can say it is a case of "sui generis", because given the principle of self-ruling has always sought historical stages and its autonomy as independent and internationally.

Its act is discretionary Kacaniku Constitution of 1990 which not only declared an independent state but here will find and the notion of the principle of self-determination as the internal advertisement of a nation and its application for recognition in the international arena.

\section{REFERENCES}

[1] Dixon M. (2009) International law; Publications AllS, Tirana.Puto A. (2002) International law; Dudaj publications, Tirana.

[2] Omar L. (1999) Principles and Institutions of Public Law; Elena Gjika publications, Tirana.

[3] Rrahimi Sh. (1989) the Vilayet of Kosovo; Pristina.

[4] The group of authors. (2007) History of State and Law in Bangladesh ,Publisher, Luarasi University Press.

[5] Gurakuqi R. (2012) Albania from 1911 to 1914; UET Press, Tirana.

[6] Bajrami A. (2002) Kosovo's right in Transition, Pristina. 
[7] J. Zaganjori. (2011) Jurisprudence and International practice Publicatons Morava, Tirana.

[8] The Constitution of the Republic of Kosovo.

[9] Resolution of the conference that the Bajan - Publications Dukagjini Pristina in 2000.

[10] $1244-$ Approved by the Security Council.

[11] Article 4/1 Ahtisaari package.

[12] Special Buletin , 5 years Consitution - Consitutional court and the Commission of Venice.

[13] The decision of the International Court of Justice for deklaraen the independence of Kosovo.

[14] Omari L. (1999) Principles and insitution of public laww, Elena Gjika Publicationc ,Tirane.

[15] Dixon M, international law; Publications AllS, Tirana.

[16] Puto A. (2002), international law; Dudaj publications, Tirana.

[17] Omari L. (1999), Principles and insitution of public laww; Elena Gjika Publicationc, Tirane.

[18] Special Buletin , 5 years Consitution - Consitutional court and the Commission of Venice.

[19] Rrahimi Sh. (1989), the Vilayet of Kosovo; Pristina.

[20] The group of authors. (2007), History of State and Law in Bangladesh .. Publisher: LUARASI University Press.

[21] Gurakuqi R. (2012), Albania from 1911 to 1914; UET Press, Tirana.

[22] Bajrami A. (2002), Kosovo's right in Transition; Pristina.

[23] Gjeorgjeviq J. ( 1972), Constitutional Law ; Prishtine

[24] Bajrami A. (2002), Kosovo's right in Transition; Pristina.

[25] Bajrami A. (2002), Kosovos Right,s Transition ;Prishtine.

[26] J . Zaganjori. (2011), jurisprudence and international practice; Published Tirana: Morava;

[27] $1244-$ By the secyrity council

[28] Ahtisaari package.

[29] Basic provisions of the constitution of Kosovo.

[30] J . Zaganjori. (2011), jurisprudence and international practice; Published Tirana: Morava; 